\title{
Improved Value Generation from Residual Resources in Iceland: the First Step Towards a Circular Economy
}

\author{
David Christian Finger ${ }^{1,2,3}$ - Gudrun Saevarsdottir ${ }^{1,3} \cdot$ \\ Halldór Guðfinnur Svavarsson ${ }^{1,4}$ • Bryndís Björnsdóttir ${ }^{5}$ - Sigurjón Arason ${ }^{5,6}$. \\ Lea Böhme ${ }^{7}$
}

Received: 5 November 2020 / Accepted: 4 February 2021 / Published online: 3 March 2021

(C) The Author(s) 2021

\begin{abstract}
Improved value generation and efficient use of resources are important steps national economies can implement to minimize the use of resources and mitigate the creation of waste and toxic emissions. The increase of resource efficiency is eminent to tackle the imminent challenges of depleting resources and the emerging environmental crisis. In this study, we explore the value generation and efficiency of resource recovery in waste streams in the most important economic sectors in Iceland, namely, (i) fisheries, (ii) domestic waste processing, (iii) geothermal energy production, and (iv) aluminium production. By describing the processes, the opportunities, and the market potential of the value generation through enhanced resource efficiency in the four case studies, we identify possible solutions towards a more sustainable society. The results reveal that the increase in resource efficiency reduces the environmental impacts, increases the economic output, and enhances the resilience of the economy. We conclude that the presented concepts of added value generation could be the first step towards a circular economy, adhering to a more sustainable world while preserving vital resources for the next generations. While our results are based on the presented examples in Iceland, the described processes of resource recovery can be applied in any other country with similar resources.
\end{abstract}

Keywords Iceland $\cdot$ Resource efficiency $\cdot$ Sustainability $\cdot$ Circular economy

\section{Introduction}

In 2009, Rockström et al. (2009) [1] published their widely acknowledged paper on the safe operating space for humanity. In their work, Rockström et al. identified nine planetary boundaries that are being jeopardized by modern society, namely, (i) climate change, (ii)

David Christian Finger

davidf@ru.is; fingerd@gmx.net

Extended author information available on the last page of the article 
chemical pollution, (iii) ozone depletion, (iv) aerosols loading, (v) ocean acidification, (vi) biochemical flows, (vii) freshwater use, (viii) land change systems, and (ix) biosphere integrity. In order to remain in the safe operating space, it is of imminent importance that modern society starts to reduce resource waste and pollution, recycle and reuse resources, treat toxicity of waste before release, and control the disposal of residual streams to avoid harm to the natural environment. Numerous studies and projects have investigated and suggested innovative solutions to adhere to the aforementioned recommendations (Fogarassy and Finger, 2020, Fogarassy et al. 2020) [2, 3]. In international networks, engineers have been pledging to adhere to the 12 principles of green design (Anastas and Zimmermann, 2003) [4]. Nevertheless, the use of natural resources and energies has increased provoking Steffen et al. (2015) [5] to draft a guideline warning from the severe consequences if the planetary boundaries are exceeded. Only 2 years later in 2017, Steffens warning was impressively repeated, this time by a huge consortium of 15000 scientists (Ripple et al. 2017) [6] warning humanity from devastating consequences if resources are not preserved. Finally, in November 2019, over 11,000 scientists declared an imminent warning of a climate emergency, asking for immediate action to preserve resources and reduce polluting emissions (Ripple et al. 2020) [7].

In the past decades, researchers have primarily been focusing on recycling, by reusing resources from the residual stream for further purposes. Unfortunately, the value of the recycled resources frequently dropped in value, lowering the incentive to recycle. This decrease of value through recycling has been labelled down cycling in the literature (Di Maria et al. 2018) [8]. A much more efficient way of preserving resources and reusing them for different purposes is described by the concept of the circular economy (Stahel 2016) [9]. The concept of the circular economy maintains the value of resources by eliminating waste and the continuous use of resources (Geissdoerfer et al. 2017) [10]. Circular systems employ reuse, sharing, repair, refurbishment, remanufacturing, and recycling to create a closed loop system, minimizing the use of resource inputs and the creation of waste, pollution, and carbon emissions (Geissdoerfer et al. 2020) [11]. Accordingly, the circular economy is an excellent way of reducing the waste of resources, mitigating emissions and at the same time generating economic value (Stahel 2016, Geissdoerfer et al. 2017) [9, 10].

The concept of reducing resource consumption, reducing emissions, and reusing resources is particularly important for small societies that are located in remote areas with limited possibilities of trading with surrounding neighbours. Nature-based solution can provide efficient solutions to reusing the resources in various waste streams (Kisser et al, 2020, Oral et al. 2020, Keesstra et al. 2018) [12-14]. Island nations are typical examples, as they have to import most of the resources, manage residual streams themselves, or adhere to cost-intensive transportation of waste to far away partners. Perhaps one of the most ingenious examples is Iceland, a north Atlantic Island nation that has emerged as one of Europe's wealthiest nations and where residents enjoy one of the highest human development index in the world. The path to Iceland wealth was hard since at the beginning of the twentieth century, Iceland was one of the poorest nations of Europe. Various developments have led Iceland to a gradual development to the innovative and modern society of the present day. The seemingly endless resources of fish, geothermal energy, and clean water resources that can be used to produce cheap and renewable electricity were assets in Iceland's path to an affluent nation. Nevertheless, these perhaps evident factors might overshadow the high ecological footprint in Iceland, which exceeds the European average footprint (https://www.footprintcalculator.org/). Indeed, Iceland has emerged as an innovative society, always striving for new technologies and using the resources for multiple purposes. 
In this paper, we provide an overview of four economic sectors in Iceland and describe how resources in Iceland are used efficiently to improve the generated value through the generation of by-products that, in some cases, contribute even more to the national gross product than the primary product. For this purpose, we analyse four sectors, namely, (i) the fisheries, (ii) the municipal solid waste, (iii) the use of geothermal resources, and (iv) the aluminium production. We present the technologies and processing concepts that lead to increased efficiency and the subsequent improved value generation in the four sectors. Finally, based on the presented results, we conclude that efficient use of resources and an improved value generation could be the first step towards a circular economy.

\section{Methods}

This paper describes the resource use and the recovery of resources from the residual streams in the main industrial sectors in Iceland. For this purpose, the following industrial sectors were analysed: (i) the fisheries, (ii) the municipal solid waste, (iii) the use of geothermal resources, and (iv) the aluminium production.

In the first step, the five sectors were described and the relevance for the national economy was highlighted. The main products produced by each sector were identified and quantified. The market value and its contribution to the national economy were then defined. Subsequently, the efficiency of the resource use, the recovery of the residual streams, the process of recovery, and the products produced with the recovered resources were identified. By estimating the market value of all products produced from the recovery of resources in the residual stream, the improvement of generated value was quantified. Finally, the economic value of an upscaling of the presented techniques was estimated.

\section{Fisheries}

The fishing industry of Iceland accounted for about $6 \%$ of the GDP in 2018 but has fluctuated between 5 and $10 \%$ in the last decade. Over $4 \%$ of the Icelandic population worked directly within the fisheries industry in 2018 , of which over $80 \%$ were employed outside of the capital region, and many more worked in related industries and in servicing the fishing industry. Around $98 \%$ of the total value of the catch is exported, which in 2018 was 671 thousand tonnes with a value of 1.88 billion EUR of seafood products. Of this, the most valuable species is the Atlantic cod (Gadus morhua) (see Table 1). In 2018, 76\% of Iceland's seafood was exported to the UK, France, Spain, Norway, the USA, Germany, China, the Netherlands, Portugal, and Japan. Aquaculture is a growing sector within the fishing industry in Iceland, based primarily on the production of Atlantic salmon (Salmo salar) and Arctic char (Salvelinus alpinus) with an export value of 103 million EUR in 2018, representing more than $90 \%$ of the total production (Source: Statistics Iceland, accessed through https://radarinn.is/).

Through extensive research and development, catching, handling, processing, and transport of the catch have been improved tremendously in the last decades, resulting in significant value creation through improved quality and utilization and production of higher-value products. Along with the increased value of traditional fish products, the focus on improved quality and utilization has simultaneously opened new possibilities and interest in the development of value-added products from side streams, which previously have been discarded or 
Table 1 Export of seafood from Iceland in 2018 by volume and value

\begin{tabular}{lll}
\hline Species $^{\mathbf{a}}$ & Volume (kt) & Value (million Euro) \\
Cod & 132 & 786 \\
Groundfish species (excl. cod) & 177 & 541 \\
Pelagic species & 270 & 390 \\
Shellfish & 15 & 100 \\
Other seafood & 77 & 60 \\
Total & 671 & 1877 \\
Cod Products & Export volume (kt) & Value (million Euro) \\
Whole (frozen, fresh) & 11.647 & 36 \\
Fillets (fresh) & 29.330 & 274 \\
Fillets (frozen) & 48.103 & 277 \\
Salted (split, fillet) & 21.041 & 133 \\
Total main products & 110.121 & 720 \\
Side Products from Cod & Export volume (kt) & Value (million Euro) \\
Dried & 12.797 & 38 \\
Frozen & 32.560 & 27 \\
Salted & 1.722 & 4 \\
Viscera & & \\
- Liver & 8.570 & 42 \\
- Roe & 2.073 & 7 \\
- Milt & 677 & 2 \\
- Other & 505 & 1 \\
Total Side Products from Cod & 58.944 & 121 \\
\hline
\end{tabular}

${ }^{a}$ Estimates from Statistics Iceland (https://radarinn.is/)

used to produce low-value products. This has led to the fact that in Iceland, the utilization of wild fish catches is higher compared to the North Atlantic average, or above $80 \%$ when it comes to utilization of cod (Viðarsson et al. 2015) [15]. An important reason for this success is the consolidation within the fishing industry and vertical integration across the value chain, as vertically integrated companies both collect and handle the raw materials to make high-value products (Laksá et al. 2016) [16].

The number of utilized species and processing techniques leads to a great diversity of recovered side streams. Therefore, to simplify the case, the examples below are restricted to cod, its methods of processing, generated side streams, and end products. Cod was selected, as it is the single most valuable species and its utilization is furthest developed.

The processing of cod varies depending on the targeted end products. The primary product of fish is the main muscle, the fillet. What remains are here referred to as side products. Cod is sold as a whole, headed and/or gutted, split, in fillets or fillet portions, etc. and as a chilled, frozen, salted, dried, or otherwise preserved product (Fig. 1a). The estimated average ratio of the cod fillet and other raw materials is shown in Fig. $1 \mathrm{~b}$.

Today, most of the side streams from cod processed on land are utilized, while full utilization at sea is more difficult as many vessels are not equipped to handle and store the raw materials. The main side streams from cod processing are the following: livers, which are sold chilled, frozen, or canned or used for fish oil production, and roes (hard and soft), sold fresh or processed. Heads and backbones are dried, salted, and frozen for human consumption or used in meal production. From heads, cheeks and tongues can be sold separately. Trimmings and cut-offs are used to produce mince. Fish skins are used for collagen and gelatine production or dried for feed; they have also been used in high-value products such as tanning to produce textiles and for tissue regenerating medical products. Viscera are used as feed and fertilizer and as a source of enzymes. Several different side streams can be and are used to produce fish protein hydrolysates (FPH), where the 
a) Relative export value

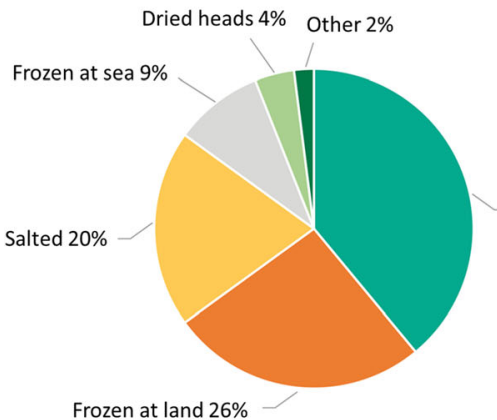

b) Ratio of raw materials

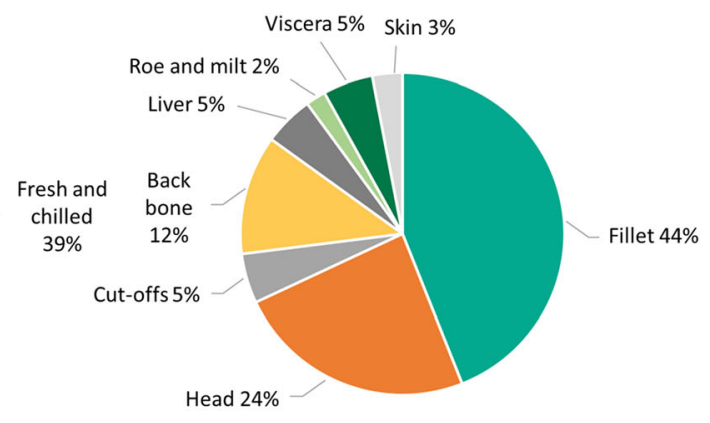

Fig. 1 a Relative export value by cod product groups in 2018. Source: Statistics Iceland. b Ratio of raw materials in the processing of skinless and boneless cod fillets (adapted from Arason et al. 2009 [17])

proteins in the raw material are broken down and used as food ingredients or supplements. Side streams, such as cut-offs, frames, and backbones, are also currently processed into the feed and sometimes flavour extracts but have the potential to be developed into higher-value products (Jónsson et al. 2016) [18]. Many possibilities to use other side streams, such as milt and eyes, exist, as well as developing higher-value products from currently utilized raw materials. Many examples of such developments can be found in Iceland. Figure 2 shows a schematic representation of the full utilization of all the side streams.

Data on the available side streams and their quantities are scarce, and they fluctuate between seasons, fishing grounds, processing methods, and the size of the catch. From the available data, a conversion factor has been estimated for cod, which can be used to calculate the total hypothetical volume of side streams (Laksá et al. 2016) [16]. In Table 1, the volume and value of exported cod products in 2018 are shown. The table contains both food and feed products but does not include numbers for some of the high-value products, such as medical products. These are not yet included in the registry of Statistics Iceland.

\section{Municipal Solid Waste}

Municipal solid waste (MSW) is different to other resources, because there is a need for collection and treatment as a service for the public, no matter the value of the material (Hoornweg and Bhada-Tata 2012) [19]. However, especially the organic fraction of the MSW (OFMSW) offers opportunities for the future. Using organic waste materials as a resource plays a key role in the European Bioeconomy Strategy towards a fossil-free and sustainable future (COM 2018) [20].

MSW of the residents of the capital area of Iceland, Reykjavik, is collected together with organic waste. In 2018 SORPA, the state-owned waste collection company of the capital area Reykjavik recorded $142 \mathrm{~kg}$ /capita domestic solid waste, thereof 50\% was kitchen and food waste (Björnsdóttir 2018) [21]. Additional organic fractions in the MSW are garden waste and, to some extent paper, personal hygiene products and textiles. The local and community-owned waste management company SORPA offers separate kerbsite collections for other recyclables such as plastics (6.9 kg/capita in 2018), paper, and cardboard (28.4 kg/capita in 2018) (Björnsdóttir 2018) [21]. Other recyclables are collected at various collection points throughout the city. 

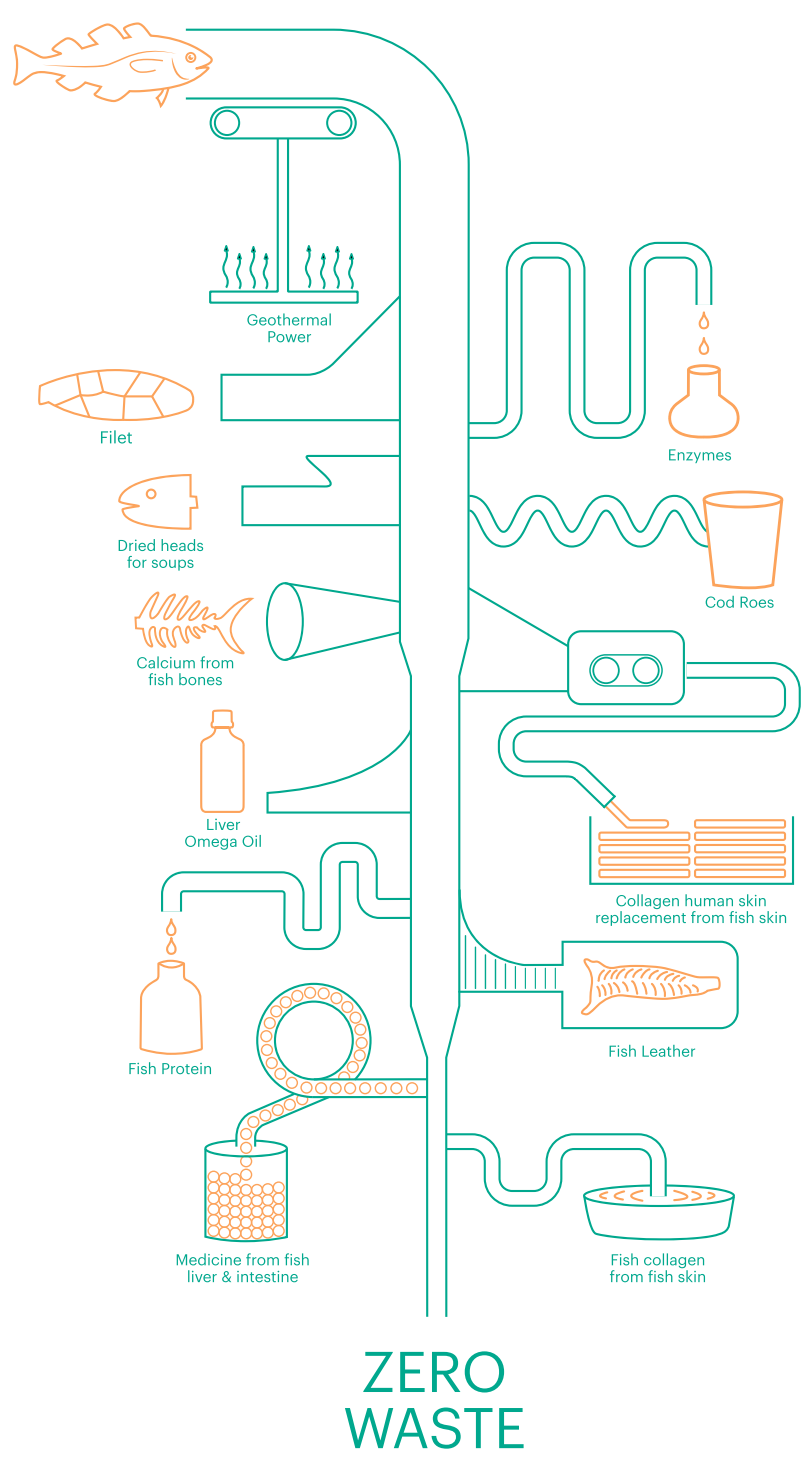

Fig. 2 Schematic representation of the different value streams from fish and their utilization. Source: the Iceland Ocean Cluster (with permission)

To recycle the organic fraction of the MSW, the waste management company is building a biogas and composting plant. It started its operation in 2020 (SORPA, 2019) as required by the European Union legislation on banning landfilling of MSW and organics to reduce landfill emissions. According to the legislation, by 2035, a maximum of $10 \%$ of MSW can be disposed in landfills, in order to minimize leachate and diffuse landfill greenhouse gases. As Iceland is a European Economic Area (EEA) member, the waste legislation of the European Union is binding (Vuorinen and Merta 2016) [22]. The other beneficial reason for Iceland to treat organic waste is material and energy recovery.

The input of the biogas and composting plant is primarily composed of the OFMSW, since the MSW is mechanically pre-treated to separate the organic fraction from the recyclable 
fractions metals and plastics at the treatment plant in Gufunes, Reykjavík (Björnsdóttir 2018) [21]. Additionally, solid derived fuel (SDF) is produced, leaving less than 5\% to be landfilled (Björnsdóttir 2018) [21], as visualized in Fig. 3. The biogas plant operates in a two-phase percolation and anaerobic wet digestion process using the Aikan® Technology (Björnsdóttir 2018) [21]. The three major output streams of the biogas and composting plant are compost, structure material, and biogas (Fig. 3). Since OFMSW is frequently of low quality and contaminated with non-organic matter (e.g. plastics), compost needs to be screened and classified to fulfil the local market criteria. The structure material is regained as the oversized grain of the compost screening and can directly be reused as fresh structure material in a closed loop. Most of the biogas is upgraded to bio-methane which can be used as carbon neutral biofuel (Björnsdóttir 2018) [21].

The estimated treatment and recovery capacities of the plant are three million $\mathrm{Nm}^{3}$ of methane (CH4) and 10 to 12 thousand tonnes of soil improver or compost (Table 2). This contributes to an efficiency increase and improved value generation in two ways: firstly, the methane is used as vehicle fuel in the capital region of Reykjavik (Björnsdóttir 2018). The direct utilization of biogas for bioenergy by upgrading it to methane has substantial environmental benefits since it is renewable, carbon neutral, and less toxic fuel (Ardolino et al. 2018) [23]. Secondly, as Iceland is exposed to soil erosion and harsh agronomic conditions (Arnalds 2000) [24], compost is a valuable resource for the local market closing the nutrient and organic carbon loop in food production (Kristjansdottir and Busch 2019) [25]. The use of compost derived from OFMSW is currently being investigated and optimized but could contribute to a substantially improved value generation (Llano et al. 2021) [26].

The biogas plant offers the capacities for future developments by adding a variety of different feedstocks. One idea is treating the protein-rich side stream and the feather and bone meal of the slaughterhouse waste together with the OFMSW, contributing to the biogas and the compost production (https://www.sorpa.is/um-sorpu/lifdisill). The fat-enriched slaughterhouse waste itself will be used for biodiesel production (https:/www.sorpa.is/um-sorpu/ lifdisill). The potential of adding different feedstocks and having specialized processes for additional products indicates that the efficacy can still be increased and the value generation

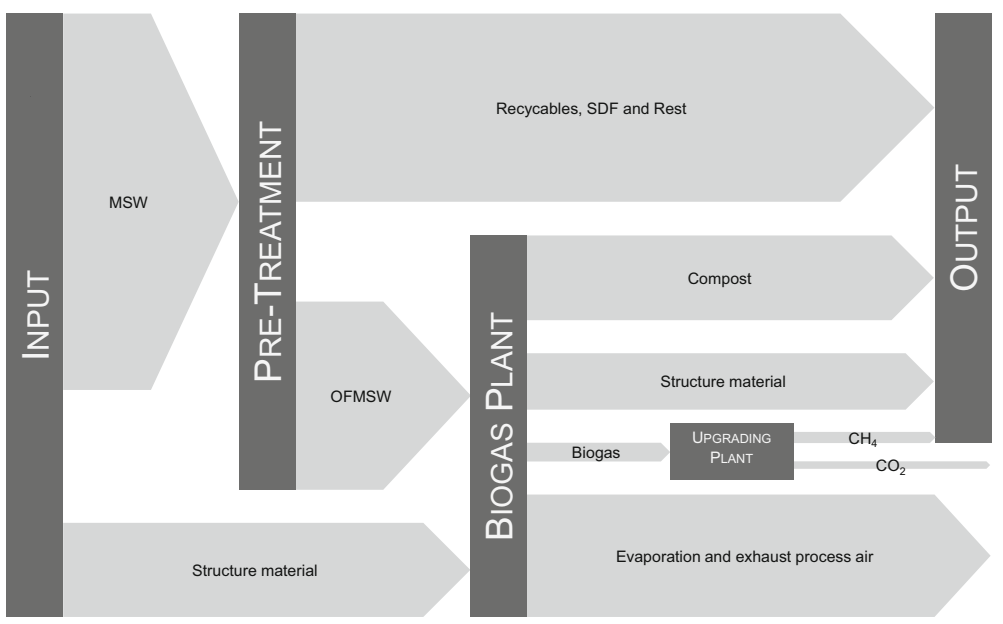

Fig. 3 Estimated mass flow of the OFMSW treatment in the biogas and composting plant (Hjarðar, 2019) 
Table 2 Overview of the planned recovery of resources from the biogas and composting plant as recorded by SORPA (Björnsdóttir 2018)

\begin{tabular}{lllll}
\hline $\begin{array}{l}\text { Resources } \\
\text { recovered }\end{array}$ & $\begin{array}{l}\text { Amount } \\
/ \mathrm{yr}\end{array}$ & $\begin{array}{l}\text { Products } \\
\text { produced }\end{array}$ & $\begin{array}{l}\text { Amount per } \\
\mathrm{yr}\end{array}$ & Potential market value \\
\hline $\begin{array}{c}35,000 \mathrm{mg} \text { organic } \\
\text { fraction of the MSW }\end{array}$ & Biogas & $\begin{array}{c}3,000,000 \\
\mathrm{Nm}^{3} \mathrm{CH}_{4} \\
10-12 \mathrm{t}\end{array}$ & $\begin{array}{c}\text { Currently 0 ISK; future potential of 200,000,000 } \\
\text { ISK (1.5 million euro) }\end{array}$ \\
\hline
\end{tabular}

improved. Nevertheless, biogas and compost production present valuable added value generations from previously unused waste streams.

\section{Geothermal Resources and Power Production}

Steam and fluid of geothermal origin are widely used for the production of electricity and district heating in Iceland. In 2005-2008, the annual direct use of geothermal heat in Iceland was equivalent to $\sim 6800 \mathrm{GWh}$, and its installed power capacity was $1844 \mathrm{MW}_{\mathrm{t}}$ and $484 \mathrm{MW}_{\mathrm{e}}$ (Arnorsson et al. 2008) [27] and has grown somewhat since then. Although normally considered a sustainable and pollution-free energy source, its utilization involves the ejection of non-condensable gases and, in some cases, salt-rich non-potable water. The geothermal power plant, HS Orka, is located in southwest Iceland on a sequence of highly porous and water permeable lava flows in several $\mathrm{km}$ distance from the coastline. Geothermal wells drilled through the lava flows to depths of up to $2000 \mathrm{~m}$ discharge $\sim 240^{\circ} \mathrm{C}$ hot fluid composed $1 / 3$ of meteoric water and 2/3 seawater that has percolated through the lava (Arnorsson 1995) [28]. The geothermal fluid contains a high concentration of silicon $(\mathrm{Si})$ in the form of silicic acid $\left(\mathrm{H}_{4} \mathrm{O}_{4} \mathrm{Si}\right)$ when it enters the wells. Steam from the flashed geothermal fluid enter turbines to produce electricity (output power of $\sim 75 \mathrm{MW}_{\mathrm{e}}$ ), and the associated liquid (condensed steam) is used in heat exchangers (output power of $\sim 150 \mathrm{MW}_{\mathrm{t}}$ ) to heat freshwater for district heating (Svavarsson et al. 2014) [29]. After the flashing of the geothermal fluid, about $2 \%$ of the volume is left as non-condensable gases (NCG), mainly composed of $\mathrm{CO}_{2}(92-96 \% \mathrm{v} / \mathrm{v})$ and $\mathrm{H}_{2} \mathrm{~S}(\sim 2 \% \mathrm{v} / \mathrm{v})$. Roughly $6 \times 10^{4}$ tonnes of NCG are being ejected annually by HS Orka.

Most of the harnessed geothermal fluid is reinjected into the geothermal reservoir, but a portion of it $\left(\sim 4 \times 10^{6} \mathrm{~m}^{3}\right.$ annually) is discharged on the surface, forming the well-known Blue Lagoon spa (see Fig. 4a). Part of the harnessed fluid is bypassed to sedimentation tanks (see Fig. 4b) where it cools to ambient temperature. Upon cooling, the fluid becomes supersaturated of the silicic acid, which in turn precipitates as amorphous silica $\left(\mathrm{SiO}_{2}\right)$. The Blue Lagoon ltd., which operates the Blue Lagoon spa, produces a wide range of cosmetics and skincare products in which the silica is an active ingredient. After collection of the silica, a portion of the geothermal fluid left is evaporated with hot geothermal steam to produce salt that is also used as an active ingredient in the cosmetics. The portion left is used as a media for the cultivation of blue-green microalgae species (cyanobacteria, Aponinum, referred to as the Blue Lagoon Algae) that is furthermore an active ingredient in the cosmetics. A tubular photobioreactor (see Fig. $4 \mathrm{c}$ and d) at the R\&D centre of Blue Lagoon ltd. is used for the cultivation. Similarly, like other plants, the algae use light to convert $\mathrm{CO}_{2}$ into biomass in a photosynthetic process. A fraction of the NCG, ejected from HS Orka, is piped to the photobioreactor as a carbon source. 

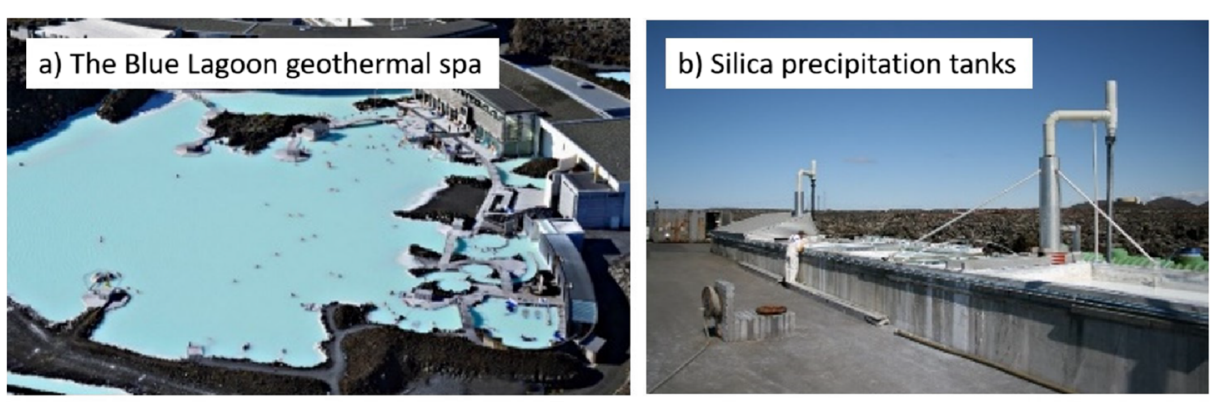

c) The schematic photobioreactor
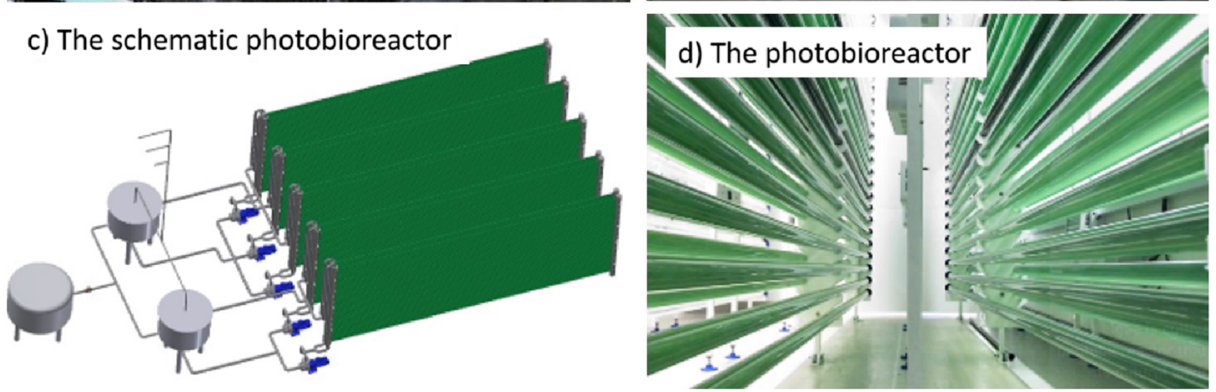

Fig. 4 a Overview photograph of the Blue Lagoon geothermal spa, Iceland; b photograph of the silica precipitation tanks used; c schematic of the photobioreactor used; and $\mathbf{d}$ photograph showing tubular pipes in the photobioreactor

The NCG contains roughly $2 \% \mathrm{H}_{2} \mathrm{~S}$ which would be detrimental for most plants but the Blue Lagoon Algae, which has adopted to the geothermal environment, is not affected by it. Over $40 \%$ conversion efficiency of the $\mathrm{CO}_{2}$ from a pristine NCG has been achieved in a pilot-scale volume $\left(4 \mathrm{~m}^{3}\right)$ photobioreactor (Svavarsson et al. 2017) [30].

Due to high mineral content in the cultivation media (geothermal fluid), it also serves as a nutrient source for the algae. Artificial lighting is provided with arrays of light-emitting diodes (LED), powered with electricity obtained from geothermal harnessing. As said earlier, the cultivated algae are a key active element in the cosmetic products together with the salt and silica that serve as an active formulating agent. Altogether, this makes a unique model of efficient use of resources and the possibility of improved value generation.

Roughly estimated, $10^{6}$ and $10^{3} \mathrm{~kg}$ of dry weight silica and algae, respectively, can be produced annually with the current facility. The product is used exclusively by the Blue Lagoon ltd - in its products and services.

With its 8-900 employees and 1 million visitors per year (as of 2018), the Blue Lagoon ltd. is one of the largest companies in the tourism industry in Iceland; its revenue in 2018 was $1.2 \times 10^{8}$ $€(120$ million $€)$ whereof the contribution of the cosmetic products was considerable $(\sim 1 / 10)$. The case of Blue Lagoon provides a unique concept of turning geothermal resource streams (gas and fluid) into high-value end products (skincare/cosmetics) and geothermal spa and clinic.

Figure 5 illustrates schematically the concept of utilizing all residual streams associated with the harnessing of geothermal resources, visualizing the generation of value by combining the power plant, the spa, and cosmetic production. The primary source is the $\sim 240^{\circ} \mathrm{C}$ geothermal fluid, composed of seawater and freshwater obtained through boreholes at up to $2 \mathrm{~km}$ depth.

The economic output of the improved value generation is significant and can still substantially be improved as summarized in Table 3 . While the numbers in Table 4 are estimates, the past years have proven that the upcycling of residual streams from the geothermal power plant 


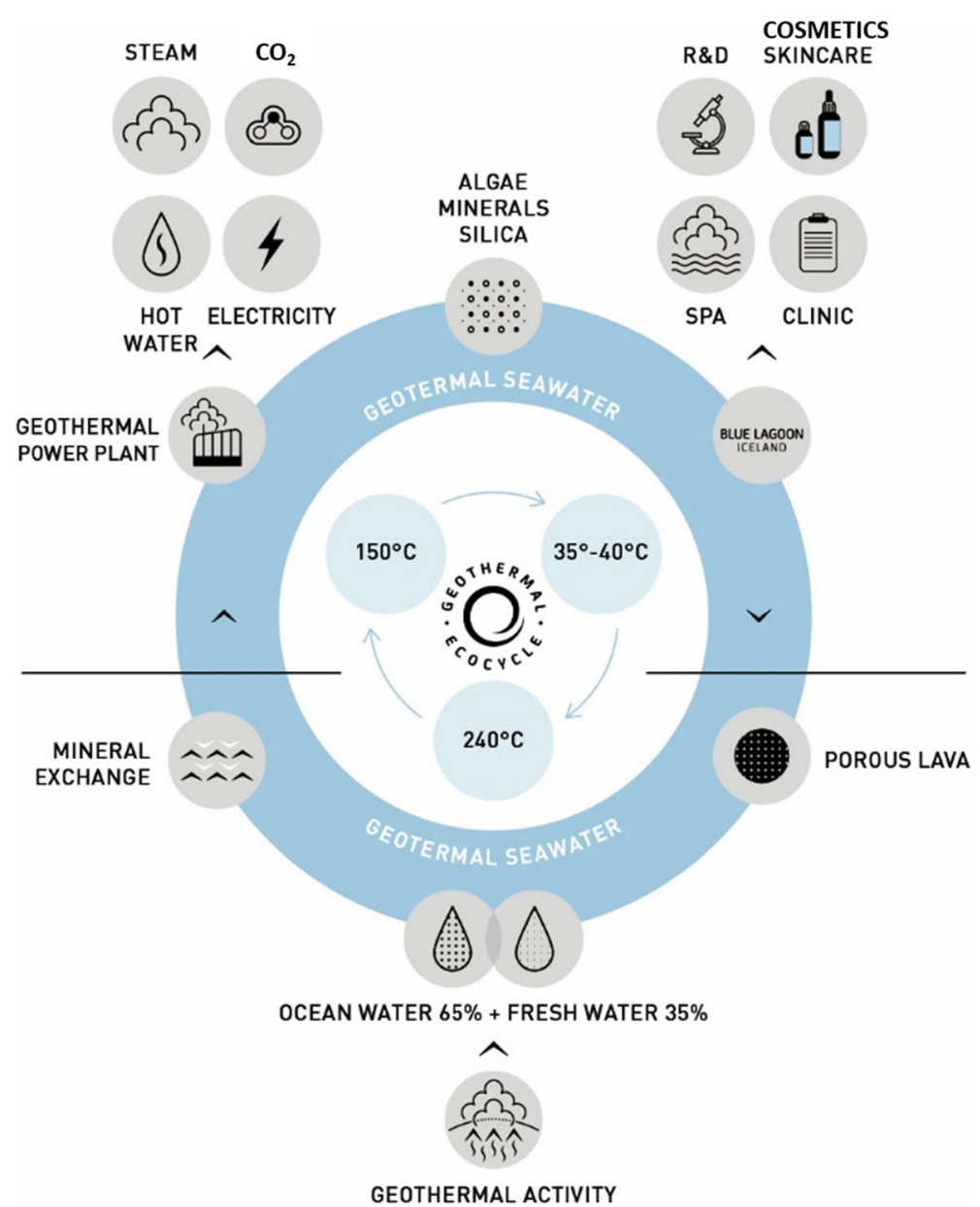

Fig. 5 Schematic overview of the recovery from geothermal resources, demonstrating the concept of utilizing all geothermal residual streams (copyright (C Blue Lagoon ltd 2019)

can generate 100 -fold the economic value of the original power plant. This illustrates the economic value of highly efficient use of a resource in the frame of geothermal power plants.

Few other examples of harnessing of geothermal gas in Iceland are found, but information on the amount produced is not confirmed. Carbon Recycling International (https://www. carbonrecycling.is/) uses a chemical process to convert geothermal $\mathrm{CO}_{2}$ from HS Orka and hydrogen gas $\left(\mathrm{H}_{2}\right)$ to $\mathrm{CH}_{3} \mathrm{OH}$ (methanol). The annual production capacity of its factory in Reykjanes, Iceland, was 5 million litres of methanol in 2017 (in news from the Icelandic national broadcasting service, https:/www.ruv.is/frett/naer-allt-metanol-flutt-ur-landi) which correspond to binding of roughly $5.3 \times 10^{3}$ tonnes $\mathrm{CO}_{2}$.

With applications in aquaculture, a company established in 2017, Algaennovation, is using a similar concept of producing algae fed on geothermal gas from the geothermal powerplant Hellisheidarvirkjun in Hellisheidi, Iceland.

A producer of industrial gas, AGA (https:/www.aga.is/en/index.html), also collects $\mathrm{CO}_{2}$ obtained from geothermal boreholes in Grimsnes, partly for greenhouse applications and for production of solid $\mathrm{CO}_{2}$ (dry ice; https://www.mbl.is/greinasafn/grein/378213/ (in Icelandic). 


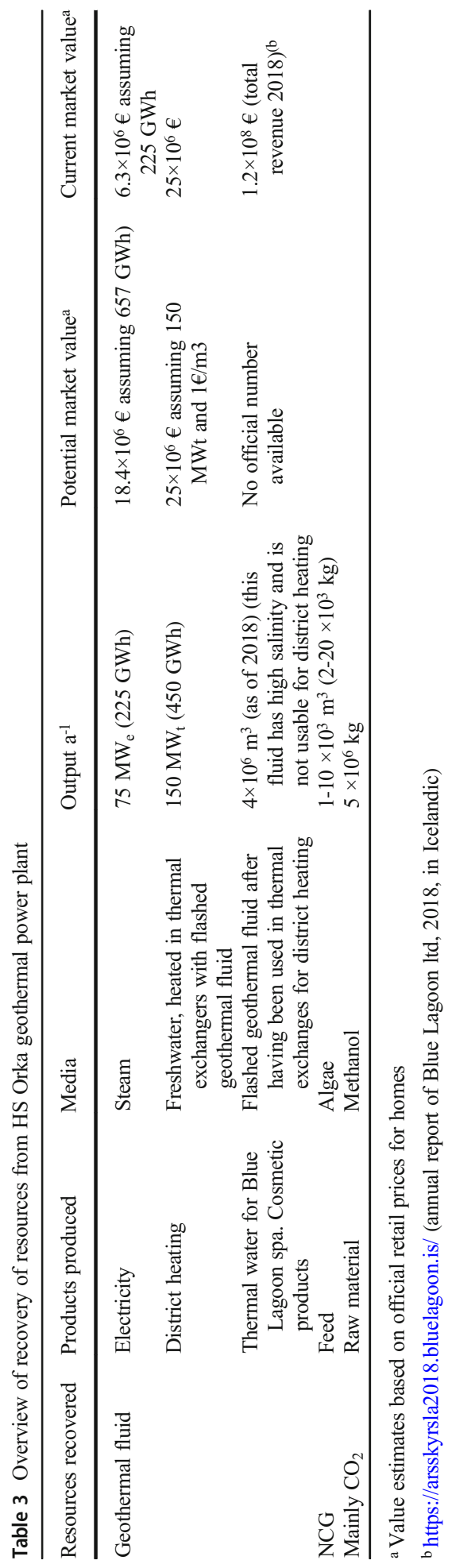


Table 4 Overview of recovery of resources from HS Orka geothermal power plant

\begin{tabular}{|c|c|c|c|}
\hline $\begin{array}{l}\text { Waste } \\
\text { product }\end{array}$ & Current management & Efficiency enhancing solution & $\begin{array}{l}\text { Potential for upscaling or } \\
\text { circular solutions }\end{array}$ \\
\hline $\begin{array}{l}\text { Hydrogen } \\
\text { fluoride } \\
\text { HF }\end{array}$ & $\begin{array}{l}\text { HF in flue gas adsorbed on } \\
\text { alumina particles in GTC } \\
\text { and recycled to the cells } \\
\text { with the raw material }\end{array}$ & $\begin{array}{l}\text { HF is absorbed on alumina raw } \\
\text { material in a dry scrubbing } \\
\text { reactor }\end{array}$ & $\begin{array}{l}\text { Around } \sim 15 \mathrm{~kg} \mathrm{HF} / \mathrm{t} \mathrm{Al} \text { is } \\
\text { recycled rather than emitted, } \\
\text { and thus } \sim 20 \mathrm{~kg} \mathrm{AlF}_{3} / \mathrm{t} \mathrm{Al} \text { is } \\
\text { saved }\end{array}$ \\
\hline $\begin{array}{l}\text { Waste heat } \\
@ \sim 110 \mathrm{C}\end{array}$ & $\begin{array}{l}\text { Not recovered in many places } \\
\text { but technically possible }\end{array}$ & $\begin{array}{l}\text { The waste heat of each smelter } \\
\text { could potentially be } \\
\text { recovered and used. i.e. for } \\
\text { space heating improving } \\
\text { efficiency }\end{array}$ & $\begin{array}{l}\text { The potential to fulfil the space } \\
\text { heating needs of around } 5 \\
\text { thousand homes, or as part } \\
\text { of the energy required for } \\
\text { CCS }\end{array}$ \\
\hline $\begin{array}{l}\mathrm{CO}_{2}, \sim 1 \% \\
\quad \text { in flue } \\
\text { gas }\end{array}$ & $\begin{array}{l}\text { Low } \mathrm{CO}_{2} \text { concentration makes } \\
\text { recovery challenging, but } \\
\mathrm{R} \& \mathrm{D} \text { is ongoing }\end{array}$ & $\begin{array}{l}\mathrm{CO}_{2} \text { can be sequestered or used } \\
\text { for synthetic fuel production } \\
\text { reducing } \mathrm{GHG} \text { emissions }\end{array}$ & $\begin{array}{l}\text { Potential } \mathrm{CO}_{2} \text { emission } \\
\text { reduction of around } 1.5 \mathrm{~kg} \\
\mathrm{CO}_{2} \mathrm{e} / \mathrm{kg} \mathrm{Al}\end{array}$ \\
\hline $\begin{array}{l}\text { Spent pot } \\
\text { lining }\end{array}$ & $\begin{array}{l}\text { Currently, around } 40 \% \text { is sent } \\
\text { for recycling; the rest is } \\
\text { disposed of in ocean landfill }\end{array}$ & $\begin{array}{l}\text { Around } 20-40 \mathrm{~kg} \mathrm{SPL} / \mathrm{t} \mathrm{Al} \text {, } \\
\text { half of that is carbon which } \\
\text { can be used for fuel under } \\
\text { the right conditions. The rest } \\
\text { can be recycled to construc- } \\
\text { tion materials after treatment } \\
\text { improving efficiency }\end{array}$ & $\begin{array}{l}\text { Currently around } 15,000 \mathrm{t} \mathrm{a}^{-1} \\
\text { of SPL is disposed in ocean } \\
\text { landfill, of that around } 7,000 \\
\text { tonnes of carbon material } \\
\text { could be combusted as fuel } \\
\text { under the right conditions, } \\
\text { and around } 8000 \text { tonnes be } \\
\text { used for building materials } \\
\text { after treatment }\end{array}$ \\
\hline $\begin{array}{l}\text { Aluminium } \\
\text { dross }\end{array}$ & $\begin{array}{l}\text { Currently, all aluminium dross } \\
\text { is recycled }\end{array}$ & $\begin{array}{l}\text { Metal separated from oxides } \\
\text { and recycled oxides and } \\
\text { other non-metallics can be } \\
\text { used as a component for } \\
\text { building materials [31] }\end{array}$ & $\begin{array}{l}\text { Around } 7000 \text { tonnes of } \\
\text { aluminium dross is recycled } \\
\text { annually }\end{array}$ \\
\hline $\begin{array}{l}\text { Aluminium } \\
\text { scrap }\end{array}$ & $\begin{array}{l}\text { Currently, all aluminium scrap } \\
\text { produced is recycled } \\
\text { internally }\end{array}$ & $\begin{array}{l}\text { Metallic scrap from the cast } \\
\text { house is recycled into } \\
\text { furnaces and re-cast }\end{array}$ & $\begin{array}{l}\text { Very dependent on the cast } \\
\text { house design, complicated } \\
\text { cast houses with advanced } \\
\text { products produce significant } \\
\text { amounts of scrap, while } \\
\text { simpler cast houses } \\
\text { producing ingots have less }\end{array}$ \\
\hline $\begin{array}{l}\text { Excess } \\
\quad \text { electro- } \\
\text { lyte }\end{array}$ & $\begin{array}{l}\text { Sold to other smelters or reused } \\
\text { in ACM. As most modern } \\
\text { smelters are self-sufficient in } \\
\text { bath, this material can be } \\
\text { hard to sell }\end{array}$ & $\begin{array}{l}\text { Sold to smelters that need to } \\
\text { feed electrolyte to the cells, } \\
\text { or who are starting cells, } \\
\text { reused in anode cover } \\
\text { material }\end{array}$ & $\begin{array}{l}\text { Annually around } 4500 \text { tonnes } \\
\text { of electrolyte are tapped } \\
\text { from cells in Iceland, } \\
\text { alternative uses for this } \\
\text { material could be desirable }\end{array}$ \\
\hline Anode butts & $\begin{array}{l}\text { Cleaned, crushed, and reused } \\
\text { as raw material for new } \\
\text { anodes }\end{array}$ & Reuse for new anodes & $\begin{array}{l}\text { Around } 110,000 \text { tonnes of } \\
\text { anode butts are recycled into } \\
\text { new anodes each year }\end{array}$ \\
\hline Anode rods & Cleaned, repaired, and reused & Reuse for new anodes & $\begin{array}{l}\text { Around } 800,000 \text { anode rods pr. } \\
\text { year }\end{array}$ \\
\hline
\end{tabular}

This illustrates the potential for other options to produce high-quality products from the residual streams of geothermal power plants.

\section{Metallurgy Industry}

Aluminium metal is attractive for recycling as the energy needed for remelting is only $5 \%$ of the energy required for primary production (Sverdrup et al. 2015) [32]. As a light-weight metal with 
good corrosion properties, the demand for aluminium has according to the main producers (e.g. Rusal, Alcoa, Norsk Hydro) increased by $\sim 5 \%$ annually since 2000, and about three-quarters of the aluminium is recycled. Much of the aluminium is used in the transport sector (30\%) and civil engineering applications (60\%) which implies a lifetime of several decades. Accordingly, the primary aluminium production is predicted to have a flat maximum about 2060 and afterwards slowly decline (Sverdrup et al. 2015) [32]. To minimize the carbon footprint of primary aluminium production, the largest gains are made by sourcing the electric energy for the electrolysis process from renewable sources, as on average $3 / 4$ of the emissions from bauxite mining to consumer product are indirect emissions due to the electricity used in the electrolysis process. The emissions from the electrolysis process can range from 1.6 to $16 \mathrm{~kg} \mathrm{CO}_{2} \mathrm{e} / \mathrm{kg} \mathrm{Al}$ depending on the electricity source (Saevarsdottir et al. 2019) [33]. Iceland is a sparsely populated island, with highlands, glaciers, and a climate rich in precipitation. This offers the potential for hydropower production. The Icelandic energy sector has historically developed and expanded based on long-term contracts with energyintensive industries seeking affordable renewable power, mostly primary aluminium production and metallurgical grade silicon/ferrosilicon production, consuming around $70 \%$ of the total power production in 2018 (OS, 2019) [34]. According to the Environmental Agency of Iceland, there are three smelters with a combined production of primary aluminium of $870,000 \mathrm{t} \mathrm{y}^{-1}$ in 2018 and $150,000 \mathrm{t} \mathrm{a}^{-1}$ in two smelters producing silicon. Aluminium scrap in Iceland is collected, and most of it is exported for recycling, although some is remelted by local foundries. Therefore the focus of this chapter is on efficiency improvements and emission reduction in the primary production of the metal (Fig. 6, Table 4).

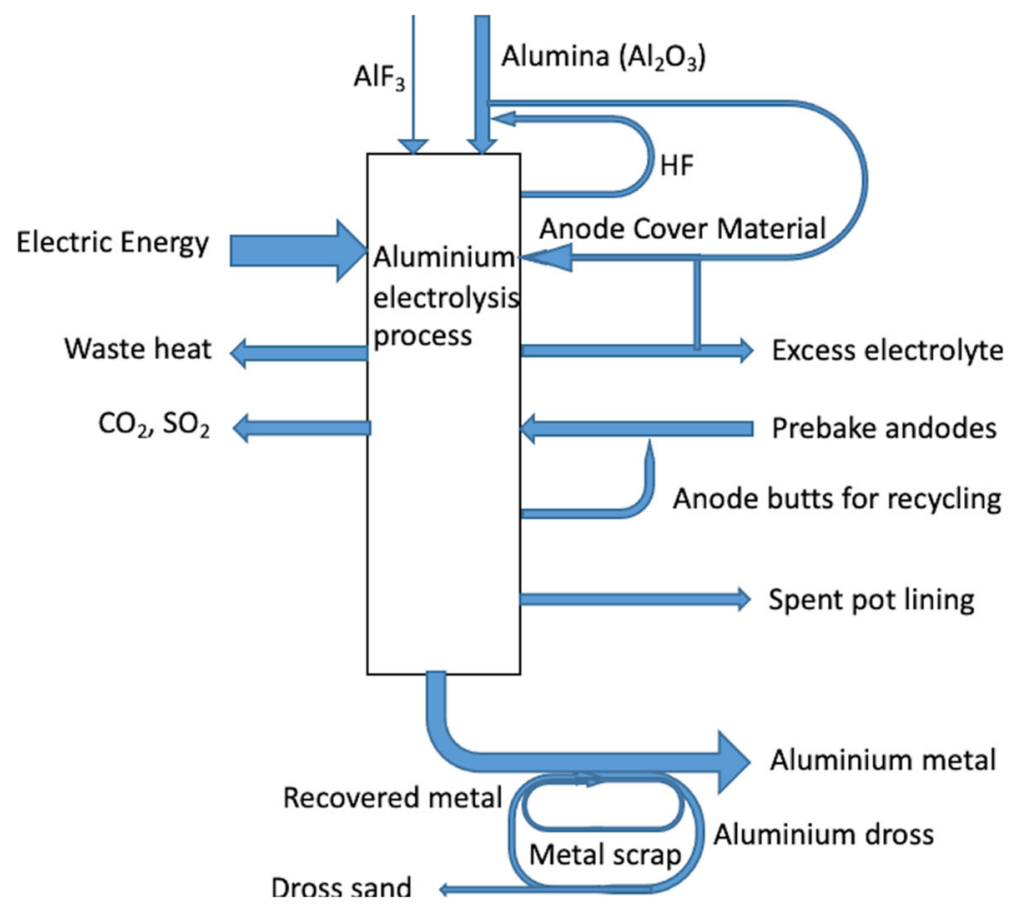

Fig. 6 A flow scheme showing material flow in primary aluminium electrolysis; some streams are recycled into the process, while others are directed to external processing or not recycled to date 
Aluminium is produced in the Hall Héroult process by electrolytic deposition of aluminium, from dissolved alumina, $\mathrm{Al}_{2} \mathrm{O}_{3}$, in large industrial cells. The main raw material, alumina, is extracted from Bauxite using the Bayer process, mostly close to Bauxite mines, and is imported to Iceland. Another important raw material is the pre-bake carbon anodes that are consumed in the process. There is no anode-baking facility in Iceland, so the pre-bake anodes are imported. The electrolyte in the process is a molten salt, based on cryolite, $\mathrm{Na}_{3} \mathrm{AlF}_{6}$. It is mixed with other fluorides, mostly $\mathrm{AlF}_{3}$, in order to maintain a process temperature of around $960^{\circ} \mathrm{C}$. The alumina is dissolved in the electrolyte, and as DC electric current of hundreds of kiloamper passes from anode to cathode, the alumina decomposes electrolytically and forms aluminium metal and subsequently settles to the bottom of the electrolyte solution. The oxygen in the alumina combines with pre-bake carbon anode and forms $\mathrm{CO}_{2}$. The stoichiometry of the reaction is:

$$
2 \mathrm{Al}_{2} \mathrm{O}_{3}+3 \mathrm{C}=4 \mathrm{Al}+3 \mathrm{CO}_{2}
$$

According to World Aluminium, the average power consumption for this process is around $14 \mathrm{kWh} /$ $\mathrm{kg} \mathrm{Al}$. As the reaction occurs at almost $1000^{\circ} \mathrm{C}$, close to half this energy is lost as heat, either through the cell walls or with the flue gas leaving the process. The heat of this process can be recovered and used for district heating or other purposes (Haraldsson et al. 2019) [35], representing the first step in recovering valuables energy resources. Nevertheless, the flue gas is typically diluted with ambient air to maintain the air quality in the pot-room and accordingly the temperature drops to about 100$130{ }^{\circ} \mathrm{C}$, while the $\mathrm{CO}_{2}$ content is close to $1 \%$ (Lorentsen et al. 2009) [36]. There are ongoing ambitions to recover this $\mathrm{CO}_{2}$, either for reuse or carbon capture and sequestration (CCS), but this is complicated by the low percentage of $\mathrm{CO}_{2}$ in the flue gas. As humidity is carried to the cell with input materials, hydrogen fluoride (HF) gas is also formed in the process and released to the flue gas, which would be a significant environmental hazard if released untreated into the open air. Therefore, modern smelters are equipped with gas treatment centres (GTC), where HF is led to a dry scrubbing reactor and captured by absorption to the alumina raw material and recycled by feeding the "charged" alumina to the cell (Mcintosh et al. 2016) [37]. Before the GTC units were common, the loss of $\mathrm{HF}$ had to be supplemented by adding significant amounts of $\mathrm{AlF}_{3}$ to the cell, but in modern smelters, $\mathrm{AlF}_{3}$ supplement is added in modest amounts as needed to balance electrolyte composition for $\mathrm{NaO}$ contamination of the alumina. As a result, electrolyte slowly builds up in the cell and must be tapped. As the anodes are consumed, they must be replaced by new anodes, and the retrieved anode "butts" are recycled and make up around $20 \%$ of the weight of new anodes. Before the carbon is recycled, the solidified bath which covers the butts as they are removed from the cell is first separated from the carbon, mixed with alumina, and recycled to anode cover material (ACM). As aluminium metal oxidizes easily upon contact with air, handling of molten metal leads to the formation of a mixture of metal and oxide, normally called aluminium dross, which is recycled into aluminium metal, and minerals that can be used for building materials or landfill (Mahinroostaa et al. 2018) [31]. Table 4 lists the most significant residual streams in primary aluminium electrolysis and to which extent they are currently recycled.

The lifetime of aluminium reduction cells is around 7 years, and at the end of that period, the cells are taken out of operation, all the materials in the cell are removed, and the metallic outer shell is repaired and re-lined to return to operation. The removed material is called spent pot lining (SPL) which in some cases is disposed of in ocean landfills and in others sent for recycling. There are a number of processes available for this purpose (Holywell et al. 2013, Black et al. 2016) [38, 39]. Although there are commercially operated processes for recycling or reuse of aluminium dross and SPL, both of these residual streams still pose environmental challenges, as the dross treatment 
involves, in many cases, the use of a salt flux, which must be recycled, and the SPL is still disposed of in landfill. The external steel casing is repaired and reused as a new cell.

Many of the side streams from aluminium electrolysis are currently contained in circular solutions, and there are still opportunities for improvements, in particular in the case of spent pot lining, waste heat, and $\mathrm{CO}_{2}$ from the flue gas. Icelandic industries and the research community are working closely together in order to implement and optimize the circular economy solution within the aluminium industry in Iceland. As the description above highlights, this can lead to the recovery of valuable resources and reduction of toxic and climate harming emissions.

\section{Discussion}

With growing environmental concerns and depleting resources, efficient use of resources is becoming more important than ever. Iceland has been developing and implementing various solutions to enhance efficiency and improve value generation across all major economic sectors. The impacts of the presented technologies and concepts are overwhelming and have positive effects on the environment, the society, and also the economic output.

The four case studies described in this paper represent illustrative examples of the first step in enhancing the efficient use of resources, reducing toxic emissions, and developing towards a more sustainable society. Nevertheless, the presented concepts and results demonstrate that in all four sectors, further development and improvement is needed in order to reach a circular system which avoids waste streams and minimizes negative environmental impacts. However, the presented cases generate new job opportunities for highly educated experts and provide new opportunities for improved value generation from residual streams. It is noticeable that the generated added value from the residual streams yields higher economic output than the products from the initial process.

The fisheries sector in Iceland has managed to utilize most of its resource streams to generate processed products that generate an added value from the fishing yields. This enhanced value creation became possible through innovation and development and was partly initiated by the introduction of the individual transferable quotas (ITQ), a quota system introduced in 1983 to avoid overexploitation of fishing resources (Arnason 1993) [40]. While the free trading of ITQs has raised concerns regarding the fair and equal distribution of quotas (Palsson and Helgasson 1995) [41], the system has facilitated the development of added value processing in three steps. In the first step, the limitation of fishing yields to a quota caused fishing vessels to bring a higher portion of the side streams for processing to the shore. Hence, the processing of fish has been increasingly moving from onboard onto land since 1983, making the collection of side streams easier. Secondly, the on-land processing facilitated the improvement of processing yield of all utilized species. Some of the world's leading companies in fish processing technology solutions are found in Iceland, and they are engaged in this ongoing process. Thirdly, the improved processing leads to higher-value products generated from the side streams. This includes developing novel products, channelling more volume away from lower-value products towards higher-value products and developing markets for these products. These are the current and future tasks of the fishing industry in Iceland.

Due to the low population density in Iceland, most municipal solid waste is still disposed of in landfills. A reason for this is the high costs for separate waste collection and transportation and modern recycling infrastructure, as well as exceptionally low energy prices, making incineration plants economically unsustainable. Nevertheless, since the municipal solid waste contains up to $60 \%$ of organic material, a modern biogas reactor can efficiently process organic 
waste into compost and valuable biogas which in turn can be used in any combustion engine. The compost can be used as a soil improver to sustain Icelandic agriculture and prevent soil degradation and erosion. If the biogas is effectively used for transportation and off-road machines, this can drastically help reduce GHG emissions and help Iceland achieve carbon neutrality. Furthermore, the domestically produced, carbon-free biogas reduces the dependency of Iceland on foreign petroleum and generates a prospering internal fuel industry.

In the 1930s, Iceland successfully started a shift of the domestic energy production for heating and electricity from coal and petroleum to renewable geothermal and hydropower energy. This has been a major success, but Iceland continued to improve their geothermal power plants and has successfully complemented most geothermal power plants with multipurpose complex industrial sites. The example of Svartsengi power plant and the Blue Lagoon is an overwhelming success story, providing renewable low carbon district heating and electricity, luxury cosmetic products, thermal water for the adjacent spa, and even synthetic methanol by reusing the $\mathrm{CO}_{2}$ emissions from the power plant. The efficient use of geothermal resources and its added value generation exceeds the economic benefits of the original purpose of the power plant by several magnitudes, illustrating the impressive value of implementing added value generation solutions.

The metallurgy sector in Iceland has since it started in the late 1960s provided secured labour also during economic downturns, as in 2008 when the Icelandic economy went through a serious crisis. Metallurgical processes are unavoidably linked to massive energy consumption and emissions, mostly of greenhouse gases, but also $\mathrm{SO}_{2}$ and other gases in smaller quantities. The Icelandic metallurgical sector has through technical development and continuous improvement, in collaboration with universities and research institutions, striven to reduce resource consumption, optimize industrial processes, and mitigate emissions to the environment. The case of aluminium production demonstrates the efforts of the sector to minimize environmental impacts during aluminium production, performing better than most other aluminium producers worldwide (Saeversdottir 2019). Nevertheless, the metallurgy sector is still a large emitter of $\mathrm{CO}_{2}$, and further development is needed to investigate possible solutions to reduce environmental impacts to an absolute minimum.

\section{Conclusions}

This paper presents the efficient use of resources and the possibility to improve added value generations in four major economic sectors in Iceland. The sectors were analysed, and their added value to the Icelandic economy was quantified. Our results illustrate the advantages of efficient resource use, mitigating the waste of valuable resources, reducing harmful emissions to the environment, generating additional economic value, and finally contributing to a stronger and more resilient economy. All four sectors revealed to have tremendous economic potential for further development to improve added value generation through enhanced resource efficiency. This is a promising conclusion, as it suggests that developing countries with lower economic strength can apply the presented solutions to mitigate environmental impacts while strengthening their economies. Furthermore, the presented solutions could be the first step towards a fully circular economy.

In Iceland, fisheries management is based on the sustainable use of the resource, represented by the total allowable catch quotas set each fishing year that are determined from scientific recommendations. Through continuously improving the recovery of residual streams, process improvements, and product development, the fishing industry has been able to create added 
value by increasing the resource efficiency. These added value products from side streams are now an important contribution to the economic output of the sector.

Due to its low population density, recycling of municipality solid waste is cost-intensive. However, as the municipality waste is primarily composed of organic waste, the production of biogas represents an important part of the country's ambitions to become carbon neutral by 2040. Besides this, biogas reveals to be a cost-efficient way of contributing to energy independence in Iceland.

The residual streams from geothermal power plants reveal to provide numerous opportunities for added value generation. The case study of the blue lagoon spa demonstrates impressively that the luxury products generated from the residual streams of the power plant can generate more economic value than the electricity production in the initial power plant.

Finally, enhancing the efficiency in the metallurgy sector are various, complex, and still under development. However, the close collaboration between the industry and academic institutions leads to a continuous improvement of resources recovery. The recovery of resources in combination with a $100 \%$ renewable electricity mix can lead to a significant improvement in metal products such as aluminium.

Based on these findings, we conclude that the efficient use of resources can generate economic value, stabilize the economy, and enhance the independence of the country while limiting the use of valuable resources and mitigating harmful emissions. Accordingly, the presented concepts could be an important step towards the continuous use of resources as is the case in an ideal circular economy.

\section{Declarations}

Conflict of Interest The authors declare no competing interests.

Open Access This article is licensed under a Creative Commons Attribution 4.0 International License, which permits use, sharing, adaptation, distribution and reproduction in any medium or format, as long as you give appropriate credit to the original author(s) and the source, provide a link to the Creative Commons licence, and indicate if changes were made. The images or other third party material in this article are included in the article's Creative Commons licence, unless indicated otherwise in a credit line to the material. If material is not included in the article's Creative Commons licence and your intended use is not permitted by statutory regulation or exceeds the permitted use, you will need to obtain permission directly from the copyright holder. To view a copy of this licence, visit http://creativecommons.org/licenses/by/4.0/.

\section{References}

1. Rockström J, Steffen W, Noone K, Persson Å, Chapin FS, Lambin E, Lenton TM, Scheffer M, Folke C, Schellnhuber HJ, Nykvist B, de Wit CA, Hughes T, van der Leeuw S, Rodhe H, Sörlin S, Snyder PK, Costanza R, Svedin U, Falkenmark M, Karlberg L, Corell RW, Fabry VJ, Hansen J, Walker B, Liverman D (2009) Planetary boundaries: exploring the safe operating space for humanity. Ecol Soc 14(2):32

2. Fogarassy C, Finger D (2020) Theoretical and Practical Approaches of Circular Economy for Business Models and Technological Solutions. Resources 9(6):76. https://doi.org/10.3390/resources9060076

3. Fogarassy C, Popp J, Finger D (2020) Circular Use of Resources Theoretical and Practical Approaches of Sustainable Technologies, Business Models and Organizational Innovations. Resources:172 ISBN 978-3-03936-791-7

4. Anastas PT, Zimmermann JB (2003) Through the 12 Principles GREEN Engineering. Environmental Science and Technology.:95-101

5. Steffen W, Richardson K, Rockström J, Cornell SE, Fetzer I, Bennett EM, Biggs R, Carpenter SR, de Vries W, de Wit CA, Folke C, Gerten D, Heinke J, Mace GM, Persson LM, Ramanathan V, Reyers B, Sörlin S (2015) Planetary boundaries: Guiding human development on a changing planet. Science 347(6223):UNSP 1259855 
6. Ripple WJ, Wolf C, Newsome TM, Galetti M, Alamgir M, Crist E, Mahmoud MI, Laurance WF, 15'364 scientists (2017) World scientists' warning to humanity: a second notice. Bioscience 27(12):1026-1028

7. Ripple WJ, Wolf C, Newsome TM, Barnard P, Moomaw WR, 11'258 scientist (2020) World Scientists' Warning of a Climate Emergency. Bioscience 70(1):8-12

8. Di Maria A, Eyckmans J, Van Acker K (2018) Downcycling versus recycling of construction and demolition waste: combining LCA and LCC to support sustainable policy making. Waste Management 2018(75):3-21

9. Stahel WR (2016) The circular economy. Nature 531(7595):435-438

10. Geissdoerfer M, Savaget P, Bocken NMP, Hultink EJ (2017) The circular economy - a new sustainability paradigm? Journal of Cleaner Production 2017(143):757-768. https://doi.org/10.1016/j.jclepro.2016.12.048

11. Geissdoerfer M, Pieroni MPP, Pigosso DCA, Soufani K (2020) Circular business models: a review. Journal of Cleaner Production 277(2020):123741. https://doi.org/10.1016/j.jclepro.2020.123741

12. Kisser J, Wirth M, De Gusseme B, Van Eekert M, Zeeman G, Schoenborn A, Vinnerås B, Finger D, Kolbl RS, Griessler BT, Bani A, Pavlova D, Staicu L, Atasoy M, Cetecioglu Z, Kokko M, Haznedaroglu B, Hansen J, Istenič D, Canga E, Malamis S, Camilleri-Fenech M, Beesley L (2020) A review of nature-based solutions for resource recovery in cities. Blue-Green Systems. https://doi.org/10.2166/bgs.2020.930

13. Oral H, Carvalho P, Gajewska M, Ursino N, Masi F, van Hullebusch E, Kazak J, Exposito A, Cipolletta G, Raaschou AR, Finger D, Simperler L, Regelsberger M, Rous V, Radinja M, Buttiglieri G, Krzeminski P, Rizzo A, Dehghanian K, Nikolova M, Zimmermann M (2020) A review of nature-based solutions for urban water management in European circular cities: a critical assessment based on case studies and literature. Blue-Green Systems. https://doi.org/10.2166/bgs.2020.932

14. Keesstra S, Nunes J, Novara A, Finger D, Avelar D, Kalantari Z, Cerdà A, The superior effect of nature based solutions in land management for enhancing ecosystem services (2018) Science of the Total Environment. Vol. 610-611:997-1009. https://doi.org/10.1016/j.scitotenv.2017.08.077

15. Viðarsson JR, Guðjónsson P, Sigurðardóttir S (2020) Strategies for the gradual elimination of discards in European fisheries, 2015, Grant agreement No: 633680, Deliverable No. 5.1, Project co-funded by the European Commission within the Horizon. Programme. https://doi.org/10.5281/zenodo.1204294

16. Laksá U, Laksáfoss M, Gregersen Ó, Viðarsson JR, Danielsen R, Jónsson Á, Iversen A, Ashore E (2016) A Feasibility Study. Cooperation, Nordic Fisheries, p 109

17. Arason S, Karlsdottir M, Valsdottir T, Slizyte R, Rustad T, Falch E, Eysturskard J, Jakobsen G Maximum resource utilization - value added fish by-products. 2009, Nordic Council of Ministers. Nordic Council of Ministers: 128

18. Jónsson Á, Viðarsson JR By-products from whitefish processing, 2016, Matis report 08-16, ISSN 16707192. Iceland, Matís, Reykjavik, p 39

19. Hoornweg D, Bhada-Tata P What a waste - a global review of solid waste management, 2012, pp.116, Urban Development \& Local Government Unit, Washington, DC. USA

20. COM; A sustainable Bioeconomy for Europe: strengthening the connection between economy, society and the environment, 2018, pp.14, Communication from the commission to the European parliament, the council, the European economic and social committee and the committee of the regions, COM/2018/673 final, Brussels, Belgium.

21. Björnsdóttir G, ÁRSSKÝRSLA (2018) (Annual report 2018), 2019, SORPA, Intercommunal waste company, Reykjavík, Iceland, https://sorpa.dccweb.net/media/2/sorpaarsskyrsla2018net.pdf

22. Vuorinen T, Merta E, Municipal waste management - country fact sheet Iceland 2016, European Environmental Agency, pp.13, Copenhagen, Denmark, https://www.eionet.europa.eu/etcs/etc-wmge/ products/other-products/docs/iceland_msw_2016.pdf

23. Ardolino F, Parrillo F, Arena U (2018) Biowaste-to-biomethane or biowaste-to-energy? An LCA study on anaerobic digestion of organic waste. Journal of Cleaner Production 174:462-476. https://doi.org/10.1016/j. jclepro.2017.10.320

24. Arnalds A (2000) Evolution of rangeland conservation strategies. In: Arnalds O, Archer S (eds) Rangeland Desertification. Advances in Vegetation Science. Kluwer Academic Publishers, Dordrecht, The Netherlands, pp 153-163

25. Kristjansdottir R, Busch H (2014) Towards a neutral north-the urban low carbon transitions of Akureyri, 2019, Iceland. Sustainability 2019:11. https://doi.org/10.3390/su11072014

26. Llano T, Arce C, Finger DC (2021) Optimization of biogas production through anaerobic digestion of municipal solid waste: a case study in the capital area of Reykjavik, Iceland, 2021. J Chem Technol Biotechnol. https://doi.org/10.1002/jctb.6654

27. Arnorsson S, Axelsson G, Saemundsson K (2008) Geothermal systems in Iceland. Jokull 58:269-302

28. Arnorsson S (1995) Geothermal systems in Iceland: structure and conceptual models. 1. High-temperature areas. Geothermics 24:561-602

29. Svavarsson HG, Brynjolfsdottir A, Einarsson S (2014) Adsorption applications of unmodified geothermal silica. Geothermics 50:30-34. https://doi.org/10.1016/j.geothermics.2013.08.001 
30. Svavarsson HG, Valberg JE, Arnardottir H, Brynjolfsdottir A (2017) Carbon dioxide from geothermal gas converted to biomass by cultivating coccoid cyanobacteria. Environmental Technology 39(16):1-26. https:// doi.org/10.1080/09593330.2017.1349840

31. Mahinroostaa M, Allahverdia A (2018) Hazardous aluminum dross characterization and recycling strategies: a critical review. Journal of Environmental Management 223(1):452-468. https://doi.org/10.1016/j. jenvman.2018.06.068

32. Sverdrup HU, Ragnarsdottir KV, Koca D (2015) Aluminium for the future: Modelling the global production, market supply, demand, price and long term development of the global reserves. 103:139-154. https:// doi.org/10.1016/j.resconrec.2015.06.008

33. Saevarsdottir G, Kvande H, Welch BJ (2020) Aluminum production in the times of climate change: the global challenge to reduce the carbon footprint and prevent carbon leakage. JOM 72:296-308. https://doi. org/10.1007/s11837-019-03918-6

34. Orkustofnun (2019) 2050 Recalculation of forecast from 2015 based on new data and changed assumptions, 2019, Energy Forecast Committee, OS-2019-13, ISBN 978-9979-68-519-7, The National Energy Autority of Iceland. Reykyavik, Icland

35. Haraldsson LB, Gudjonsdottir MS, Saevarsdottir MG, Valgardsson G (2019) Feasibility of a district heating system in Fjardabyggd, using waste heat from Alcoa Fjardaal. Energy Technology:23-32

36. Lorentsen OA, Dyrøy A, Karlsen M (2009) Handling CO2 eq from an aluminium electrolysis cell. Light Metals:264-268

37. Mcintosh GJ, Agbenyegah G, Hyland M, Metson JB (2016) The pivotal role of alumina pore structure in hf capture and fluoride return in aluminum reduction. JOM: the journal of the Minerals, Metals \& Materials Society 68(9). https://doi.org/10.1007/s11837-016-2004-0

38. Holywell G, Breault R (2013) An overview of useful methods to treat, recover, or recycle spent pot lining, 2013. JOM 65(11). https://doi.org/10.1007/s11837-013-0769-y

39. Black PJ, Cooper BJ (2016) Sustainable practices in spent potliner - an industrial ecoloby approach. Light metals:261-269

40. Arnason R (1993) The Icelandic Individual Transferable Quota System: A Descriptive Account. 8, 8(3):218. https://doi.org/10.1086/mre.8.3.42629066

41. Pálsson G, Helgason A (1995) Figuring fish and measuring men: the quota system in the Icelandic cod fishery, reinventing the commons, the fifth biennial conference of the international association for the study of common property, Bodoe. Norway

\section{Affiliations}

\section{David Christian Finger ${ }^{1,2,3} \cdot$ Gudrun Saevarsdottir ${ }^{1,3}$. Halldór Guðfinnur Svavarsson ${ }^{1,4}$ • Bryndís Björnsdóttir ${ }^{5}$ • Sigurjón Arason ${ }^{5,6}$. Lea Böhme ${ }^{7}$}

Bryndís Björnsdóttir

bryndis@matis.is

Sigurjón Arason

sigurjon@matis.is

Lea Böhme

lea.bohme@sorpa.is

1 Sustainability Institute and Forum (SIF), Reykjavik University, Reykjavik, Iceland

2 Energy Institute at the Johannes Kepler University, Linz, Austria

3 Department of Engineering, Reykjavik University, Reykjavik, Iceland

4 Blue Lagoon R \& D Center, Norðurljosavegur 5-9, 240 Grindavík, Iceland

5 Matis, Reykjavik, Iceland

6 Faculty of Food Science and Nutrition, University of Iceland, Reykjavik, Iceland

7 Sorpa, Reykjavik, Iceland 